\title{
Expanding the coverage of pension systems in Latin America
}

\author{
Luis Felipe Jiménez \\ Special Studies Unit, ECLAC \\ Despite the reforms undertaken by several countries in Latin \\ fjimenez@eclac.cl \\ America, the coverage of the region's pension systems \\ Jéssica Cuadros \\ remains inadequate. Underlying that circumstance are both \\ Special Studies Unit, ECLAC \\ context-sensitive factors and those of a more structural \\ jcuadros@eclac.cl \\ nature, such as the level of relative development, the \\ difficulty of covering certain segments of the labour market, \\ and the way in which the systems and incentives are \\ designed. Given the decisive influence of the structural \\ factors, the expansion of coverage will require the right \\ combination of contributory and non-contributory systems, \\ to which end this article makes some policy \\ recommendations. Forestalling poverty in old age demands \\ a combination of social insurance elements (based on saving \\ and unfunded systems) and social security, involving some \\ solidary and tax-related financing.
}




\section{Introduction}

The basic aim of any pension system is to provide people with an income after their retirement, generally after they meet some eligibility criterion such as age or incapacity to work, as each society considers appropriate. The way in which the system is arranged to finance such income is important, as is the way in which the contributions and benefits are set, but the system's effectiveness in meeting its goal depends on its including, during their working lives, those who will later be eligible for the benefits. In that sense a system's coverage is one of its most important features.

Clearly, coverage is only one consideration in judging the quality of a pension system. Several ECLAC studies have analysed others, such as the system's financial sustainability, the quality of the benefits, its degree of progressiveness and how efficiently it is run. ${ }^{1}$

An initial proxy of the effectiveness of the region's pension systems in covering the target population (taking 60 as the average age for retirement) ${ }^{2}$ yields results that are generally disappointing. In only four of the countries in table 1 (note the second column) does there appear to be adequate coverage of the target population; coverage is deficient in the other $18 .^{3}$

Table 1 also illustrates the substantial challenge involved in covering all retirees and the financial implications of doing so. Take a hypothetical case in which all retirees (those aged 60 and over) are maintained by the younger population (aged 29 to 59) through a system that provides a pension equivalent to

The authors are grateful to Oscar Altimir for his comments and suggestions.

${ }^{1}$ See the studies in the ECLAC Financiamiento del desarrollo series, as well as Uthoff and Szalachman (1991, 1992 and 1993), Schulthess and Demarco (1993) and Acuña and Iglesias (1991). See also Acosta and Ayala (2002), Packard and Shinkai (2000), Rabelo (2001) and Superintendencia de Administradoras de Fondos de Pensiones (2002).

${ }^{2}$ The figure is given solely for reference purposes. Retirement ages in the region range from 55 to 60 for women and from 60 to 65 for men.

${ }^{3}$ The figures in table 1 should be treated with caution. First, not all pensions are given on the basis of retirement age; there are many other reasons, which explains why some percentages exceed $100 \%$. Second, some countries absent from the table have no formal pension scheme, and hence the region's average effective coverage is less than the table suggests. the latter group's per capita output. In such a scenario the ratio between the two groups (the first column of table 1) gives some indication of the maximum level of income, as a percentage of GDP, that would have to be transferred to the older population. ${ }^{4}$ It is plain that the figures are very substantial, even if the replacement rates were to be far below those implicit in this calculation. Hence the need for care in broadening coverage: public efforts should focus on those who for various reasons cannot save for their old age, and saving systems should be established with appropriate incentives for those who can save.

This article examines some of the reasons for the limited coverage of pension systems and makes some policy recommendations on how to expand such coverage, thereby helping to reduce poverty among the retired population. The proposals seek to foster financial sustainability (which is crucial if the policies are to bear fruit) and to prevent the emergence of perverse incentives and moral hazards like those that have traditionally weakened the region's pension systems. The analysis prompts the conclusion that meeting the needs of the retired population demands a combination of social insurance (typically, prior saving) and social security, the latter entailing solidary tax-derived financing of certain basic benefits.

\footnotetext{
${ }^{4}$ This approximation is based on the following simplified scheme. If all output originates among the economically active population (EAP) aged 20 to 59, GDP can be expressed as GDP $=q a * E A P$, where $q a$ is the EAP's per capita output. If there is no current-account deficit, expenditure should be equal to output, which corresponds to the EAP's spending (including maintenance of minors under 20) plus that of the retired population (RP), which in this exercise consists of those aged 60 or more. In other words, $G D P=g a^{*} E A P+g r^{*} R P$, where $g a$ and $g r$ respectively represent the per capita spending of the active and retired populations. Combining the two expressions gives $q a * E A P=g a * E A P+g r * R P$. Consequently, the transfer of income to the retired population can be expressed as $(q a-g a) *_{E A P}$ $=g r * R P$. As a percentage of GDP, that is expressed as $(q a-g a)^{*} E A P /$ $q a * P A=g r * R P / q a * P A$. If spending by retirees were covered by a pension equal to the per capita output of the active population (that is, if $g r=q a$ ), then the transfer of income to the retired population as a percentage of GDP would be equal to RP/EAP, as shown in table 1. This, of course, is a maximum limit. In general the replacement rates (in this case the ratio $g r / q a$ ) are less than one.
} 
TABLE 1

Latin America: Coverage of pension systems, by country

(Proportion of beneficiaries, percentages)

\begin{tabular}{lccc}
\hline & $\begin{array}{c}\text { Population aged } \begin{array}{c}6 \text { and over/Population } \\
\text { aged } 20 \text { to } 59\end{array} \\
\text { Population aged } 60 \text { and over }\end{array}$ & $\begin{array}{c}\text { Pensioners/ } \\
\text { Total } \\
\text { population }\end{array}$ \\
\hline Uruguay & 34.5 & 151.8 & 25.8 \\
Brazil & 14.1 & 139.4 & 10.0 \\
Chile & 17.5 & 108.2 & 10.4 \\
Argentina & 27.0 & 104.6 & 13.8 \\
Trinidad and Tobago & 17.0 & 62.7 & 5.6 \\
Guyana & 14.0 & 55.9 & 3.3 \\
Panama & 14.6 & 45.2 & 3.4 \\
Costa Rica & 14.5 & 35.9 & 2.5 \\
Peru & 14.3 & 34.0 & 2.3 \\
Bolivia & 16.2 & 32.8 & 2.3 \\
Dominica & 25.0 & 31.9 & 3.5 \\
Paraguay & 12.0 & 28.5 & 1.5 \\
Mexico & 12.9 & 26.1 & 1.6 \\
Ecuador & 13.9 & 26.0 & 1.7 \\
Guatemala & 12.5 & 25.4 & 1.4 \\
Nicaragua & 11.2 & 22.3 & 1.0 \\
Colombia & 16.1 & 19.3 & 1.5 \\
Jamaica & 18.8 & 18.8 & 1.7 \\
El Salvador & 14.3 & 14.3 & 0.9 \\
Venezuela & 13.0 & 10.9 & 0.7 \\
Honduras & 12.0 & 7.9 & 0.4 \\
Barbados & 25.0 & 4.6 & 0.7 \\
\hline
\end{tabular}

Source: Prepared by the authors using data from ECLAC (2002) and from Palacios and Pallarès-Millares (2000).

\section{II}

\section{Factors affecting coverage}

Any examination of the determinants of pension coverage faces the serious problem that data are scarce and incompatible. Analysis must therefore proceed by means of a difficult comparison based on unharmonized and dispersed data, and must be illustrated by reference to specific cases.

With regard to national legal provisions, in 25 countries of the region all dependent workers must contribute to pension systems. In only 13 does the obligation cover independent workers and in 10 the latters' contributions are voluntary. Mesa-Lago, CruzSaco and Zamallon (1990) have shown that there is a substantial gap between what is laid down in the legislation and the systems' actual coverage. In an effort to understand the reasons for the limited coverage evidenced by the data, this article examines the context in which the pension systems operate, system design features that determine the level of incentives to participate, and some personal and labour market characteristics that affect the outcome.

\section{Structural factors}

a) Relative development level

Figure 1 reveals a clear connection: the number of contributors to pension systems increases in line with the level of per capita GDP. There are three main reasons for this. First, in general there is a certain correlation between income levels and the demographic transition, giving rise to greater demand for mechanisms that provide an income in old age. Second, on the supply side, the higher the development level, the greater the availability of resources (especially public funds) that can be devoted to a pension system for retirees. Third,

EXPANDING THE COVERAGE OF PENSION SYSTEMS IN LATIN AMERICA • LUIS FELIPE JIMÉNEZ AND JÉSSICA CUADROS 
FIGURE 1

Latin America and the Caribbean: Contributors/labour force, mid-1990s

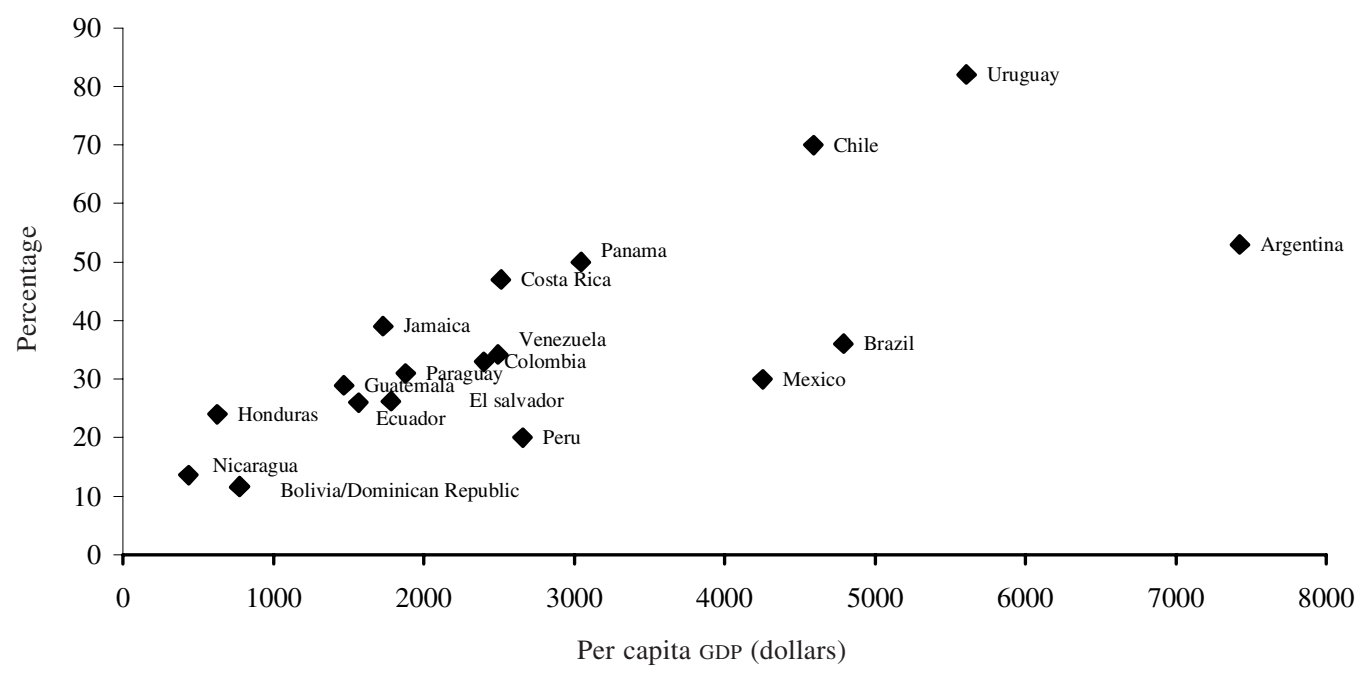

Source: Prepared by the authors using official figures and data from ILO (2000).

from the standpoint of the economic structure, the formal sector's participation in the economy and urbanization levels increase as the development level rises, which make a pension system a more feasible proposition.

There is a link between per capita output and pension system coverage, but of course it is not mechanically causal. Such systems are more the result of policies specifically designed to set up social safety nets than a spontaneous consequence of growth.

\section{b) The significance of labour market segments that are poorly covered}

In its Panorama Laboral, the International Labour Organization (ILO) presents evidence of the meagre coverage of workers in the urban informal sector. ${ }^{5}$ Also hard to cover are non-wage earners and family workers in agriculture. Using ILO statistics, figure 2 illustrates these two segments' significance in total employment and as a share of the economically active population (EAP) that contributes to social security. It shows that the percentage of contributors to social security declines as the proportion of workers who are poorly covered grows. ${ }^{6}$

\footnotetext{
${ }^{5}$ See ILO (2000).

${ }^{6}$ Table 4 presents estimates of employment that is hard to cover relative to total employment. This category is broader than the urban informal sector because it includes self-employed workers and nonwage earners in agriculture.
}

Another poorly covered segment of the labour market, separate from those mentioned above, comprises technical and professional independent workers whose economic activity is generally more formal and who are normally more productive. The reasons for this vary from case to case. In unfunded systems the explanation lies in the slenderness of the association between contributions and benefits, which makes the former seem more like a tax than payments to a scheme that will provide future income. Since enforcement is very difficult among these workers, and/ or since the contributions are voluntary, even the most skilled choose other ways of ensuring future income.

As regards saving-based systems, technical and professional independent workers find it more attractive in the short term to devote resources to developing their own economic activities than to contribute to a system whose returns are uncertain and whose liquidity is low, since in such schemes it is impossible to reallocate the contributions either to finance new activities or to avoid unwanted risks.

The irreversible nature of the contributions lies at the root of this disincentive, especially in capitalization systems where the returns are uncertain because of macroeconomic volatility and financial market fluctuations. It is highly unlikely that a majority of such workers would opt to make irrevocable contributions to systems that can suffer real losses. Even for dependent workers, whose membership and

EXPANDING THE COVERAGE OF PENSION SYSTEMS IN LATIN AMERICA • LUIS FELIPE JIMÉNEZ AND JÉSSICA CUADROS 
FIGURE 2

Latin America: Employment that is difficult to cover and contributors to social security

(Percentage of total employment and of the economically

active population, respectively)

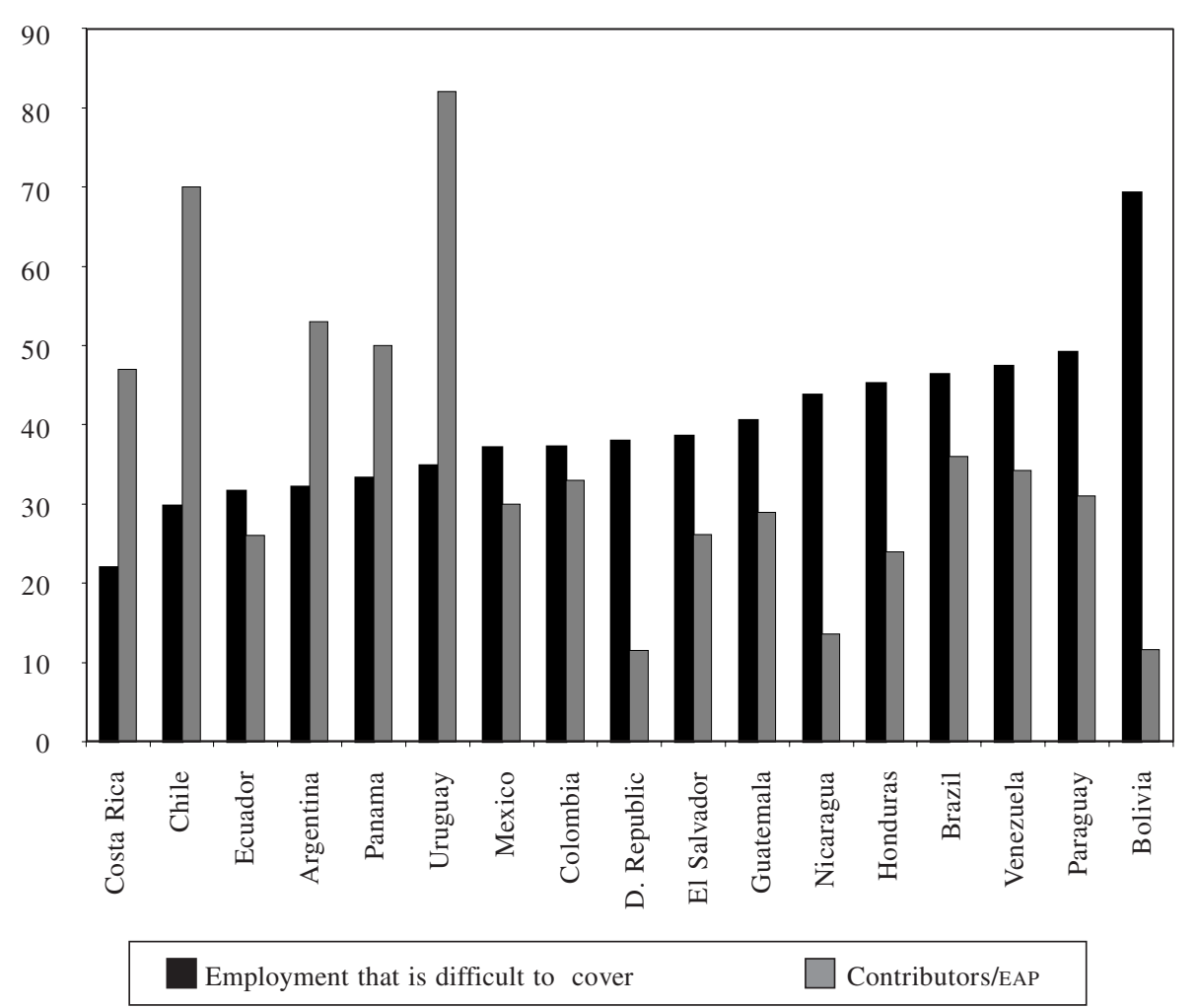

Source: Prepared by the authors.

contributions are compulsory, exposure to this risk is involuntary and probably unwanted. In both cases, obligatory exposure to risk makes social security contributions seem like taxes. The inequity of this is all the more apparent when the private pension companies are not exposed to the same risk, even though their management might cause losses.

The dilemma facing workers is aggravated by the costly commissions levied by some recently introduced systems as a means of covering administrative costs. The high level of commission discourages the participation of and contributions from those who can choose between devoting part of their resources to a system that (because of the commissions) transforms only part of their total contributions into a larger accumulated fund, or trusting in the returns that they themselves can make through their own labour or through more efficient financial alternatives. c) The disadvantaged integration of women in the labour force

The nature of the informal sector and the disadvantaged integration of women in the labour force combine to create a precarious pension situation. To understand it better, it is helpful to distinguish three stages.

First are the pre-pension-system or pre-system factors, of which the most important is women's substantially lesser participation in the labour force, most particularly among lower-income sectors where a large number of women are non-salaried family workers. This circumstance stems from the greater burden of childcare in those sectors, lower educational levels that lessen the marginal benefit of joining the labour force, and a lack of local-level institutional arrangements to provide childcare services (Jiménez and Ruedi, 1998).

EXPANDING THE COVERAGE OF PENSION SySTEMS IN LATIN AMERICA • LUIS FELIPE JIMÉNEZ AND JÉSSICA CUADROS 
Women who remain at home throughout their working lives to care for the household and family run a grave risk of becoming poor, since they are generally viewed as their husbands' dependants and thus can aspire only to a widow's pension.

Second are the effects of deficiencies in the way the pension systems are designed, coupled with inadequate integration into the labour market. A larger share of women who work do so for low wages in the informal sector, their jobs are sporadic or temporary (such as domestic help) and of poor quality, often in contexts marked by non-compliance with labour legislation. ${ }^{7}$ Their membership of formal pension systems is therefore limited and discontinuous and, because they are paid less, such schemes offer them fewer benefits.

It is worth noting that these conditions obtain whether the system is a public scheme with a defined benefit or a private system of individual capitalization. The phenomena mentioned above are evident in both cases, which suggests that in general the systems have not been designed to address the significant inequality of opportunity that women face in gaining access to pension schemes.

Third are the post-system factors related to the accrual of rights. These differ depending on the scheme in question. In defined benefit pension systems the greatest disadvantage originates in women's lower incomes and less regular work records. Individual capitalization systems and private schemes feature other drawbacks. Because of women's lower contribution density and lower pay, they accrue fewer rights than men. That circumstance is aggravated by two others: women usually retire earlier and live longer than men. Thus a system that establishes a close link between contributions and benefits -equalling out the current value of both, as happens with pensions provided by private insurance schemes- will necessarily offer women lower pensions. That happens even when women accumulate the same resources as men, since their life expectancy is longer and their retirement comes earlier.

In sum, women's status in pension schemes is structurally disadvantaged. Rectifying that situation demands that systems be designed differently so as to acknowledge the difficulties facing women in securing the opportunities offered by the schemes. Those difficulties discourage them from joining formal systems.

${ }^{7}$ See ECLAC, 2000, Statistical annex.

\section{Pension scheme design and ensuing incentives}

\section{a) Contributions as savings or tax}

Thus far this article has addressed the consequences of factors related to the environment in which the pension systems operate. It is also important, however, to consider how the systems' design affects their coverage. Particularly interesting, more for its importance in the debate on reform strategies than because of its actual effect on coverage, is a comparison of the incentives for social security saving in unfunded systems and individual capitalization schemes.

One widely held view is that inadequate coverage is inherent in unfunded systems, which are marked by only a slender association between contributions and benefits: pension contributions are viewed more as taxes than as savings for old age, which leads to evasion and limited participation. An individual capitalization scheme, by contrast, which by definition links contributions and benefits, radically changes the nature of the contributions, converting them into savings and thereby fostering wider coverage.

This view has served as a basis for various reform efforts. Without entering into a discussion of the theoretical links between savings and incentives, or of the merits of capitalization as a means of ensuring the system's solvency, it can be said here that the scant empirical evidence available does not confirm the premise underpinning such a view. ${ }^{8}$

Analysis of the prototypical Chilean experience reveals that coverage has not varied greatly between the two schemes. Table 2 shows that introducing the Administradoras de Fondos de Pensiones (AFP) system and closing the Instituto de Normalización Previsional (INP) to new members did not bring about greater coverage than when only the unfunded system was available. Rather, trends in coverage reflect economic performance: coverage declines during recessions and expands in growth periods.

It is certainly important to design schemes in such a way as to relate contributions to benefits as a means of ensuring solvency. It is also important that simultaneous efforts be made to send the right signals about saving. The Chilean experience, however, should lower expectations about how effective such schemes can be in expanding coverage.

\footnotetext{
${ }^{8}$ Schmidt-Hebbel (1998) and Uthoff (2001) present different visions of the effects on saving of Chile's pension reforms. Fox and Palmer (2001) analyse design options that are also geared to protecting the solvency of the pension system.
} 
TABLE 2

Chile: Trends in pension system coverage (Percentages)

\begin{tabular}{lrrrrrrr}
\hline \multirow{2}{*}{ Year } & \multicolumn{3}{c}{ Contributors/Employed } & & \multicolumn{3}{c}{ Contributors/EAP $^{\mathrm{a}}$} \\
\cline { 2 - 3 } & AFP & INP & Total & & AFP & INP & Total \\
\hline 1975 & --- & 71.2 & 71.2 & & --- & 61.9 & 61.9 \\
1976 & --- & 65.7 & 65.7 & & -- & 57.3 & 57.3 \\
1978 & --- & 56.6 & 56.6 & & -- & 48.5 & 48.5 \\
1980 & --- & 53.3 & 53.3 & & -- & 47.8 & 47.8 \\
1982 & 36.0 & 16.6 & 52.6 & & 29.0 & 13.4 & 42.3 \\
1984 & 40.6 & 13.7 & 54.3 & & 35.0 & 11.8 & 46.8 \\
1986 & 45.9 & 11.6 & 57.5 & & 41.1 & 10.4 & 51.6 \\
1988 & 50.6 & 9.8 & 60.4 & & 46.6 & 9.0 & 55.6 \\
1990 & 50.6 & 8.1 & 58.7 & & 46.8 & 7.5 & 54.4 \\
1992 & 55.3 & 6.9 & 62.2 & & 51.8 & 6.5 & 58.3 \\
1994 & 56.2 & 5.5 & 61.7 & & 51.8 & 5.0 & 56.9 \\
1996 & 58.9 & 4.9 & 63.8 & & 55.7 & 4.6 & 60.4 \\
1998 & 58.0 & 4.2 & 62.2 & & 53.8 & 3.9 & 57.7 \\
1999 & 60.4 & 4.2 & 64.6 & & 55.0 & 3.9 & 58.9 \\
\hline
\end{tabular}

Source: Arenas de Mesa and Hernández (2001).

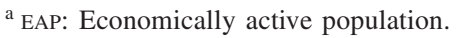

b) Inconsistent incentives caused by generous but unsustainable benefits

Robust statistical data are unavailable, but it seems clear that some systems are designed with inappropriate incentives that might lead to lower levels of participation. Some social security systems, for example, grant benefits not only to the spouse and dependent children but to other family members who are of working age. Since the health and pension programmes are indivisible, and since the benefits are extended to working-age family members, only one member joins; the marginal advantages of another's joining are less than the costs. In other words, there is a short-term personal incentive to make contributions but a disincentive for the family to do the same (Hernández Licona, 2001).

These practices spring from differences in national economic conditions and they affect the system's financial stability because, if the number of contributors falls and the number of beneficiaries grows, the expansion of coverage is unsustainable. In some cases, moreover, there is an implicit incentive to work in the informal sector since the benefits extend to workingage family members who are apparently jobless in the formal sector (but who work in the informal sector).

c) Weaknesses in the portability of workers' funds

Another cause of limited coverage is that workers cannot transfer their funds from one pension scheme to another without losing the benefits. To receive a pension, moreover, they have to have made contributions for some minimum period, but due account is not taken of the length of time that they have been affiliated to other schemes, or of the contributions made to them. In these circumstances it is likely that workers will opt not to join the schemes, which will reduce labour mobility and encourage informal activity.

The reforms undertaken in the region have sought to address this matter and increase portability by establishing various means of creating (and rebuilding) personal records covering job history and contributions.

d) Credibility of the system

It is often argued that negative perceptions of the unfunded systems' capacity to offer benefits has undermined membership. Various circumstances have eroded the system's credibility and discouraged participation, including a decline in the real value of the pensions as a result of inflation and subsequent budgetary adjustment, and the evidence of inefficiency and excessive delays.

This argument featured prominently in the emphasis placed on the total or partial privatization of pension systems in some countries. The underlying premise is that private management of the funds should make the pension system independent of political decisions, improve its efficiency and ensure a better allocation of accumulated resources, thereby enhancing the system's credibility and building confidence in it. The broad issues of efficiency and resource allocation are beyond the scope of this article; they have been addressed by Rodríguez and Durán (2000) and Mastrángelo (1999). Those analysts show that the reforms have not substantially improved efficiency and that efficiency considerations have little bearing on people's decision to join the new schemes. Recent experience, moreover, suggests that the system's independence from political pressure does not necessarily originate in its separation from the State apparatus but rather in general institutional and economic strength. An adverse context can affect pension schemes that are supposed to be independent. ${ }^{9}$

\section{Myopia about the need to save for old age}

One theory as to why pension systems have limited coverage rests on the argument that people are

\footnotetext{
${ }^{9}$ As part of the effort to deal with the crisis in Argentina, the Government decided to use the resources that had accumulated in the private pension funds, forcing them to accept public bonds to meet the public sector's financing needs in 2001.
} 
TABLE 3

Mexico: Occupational category, by age

(Percentage of the EAP)

\begin{tabular}{|c|c|c|c|c|c|c|}
\hline Age & $\begin{array}{l}\text { Wage earners with } \\
\text { IMSS or ISSSTE }^{\mathrm{a}}\end{array}$ & $\begin{array}{l}\text { Wage earners without } \\
\text { IMSS or ISSSTE }\end{array}$ & Employers & $\begin{array}{l}\text { Self-employed } \\
\text { workers }\end{array}$ & Unwaged & Total \\
\hline $12-15$ & 2.5 & 36.6 & 0.0 & 3.8 & 57.2 & 100.0 \\
\hline $16-25$ & 28.1 & 42.4 & 1.1 & 8.3 & 20.1 & 100.0 \\
\hline $26-35$ & 37.7 & 29.3 & 4.3 & 21.1 & 7.6 & 100.0 \\
\hline $36-45$ & 32.5 & 25.2 & 6.3 & 29.9 & 6.0 & 100.0 \\
\hline $46-55$ & 25.0 & 22.2 & 8.3 & 37.2 & 7.4 & 100.0 \\
\hline $56-65$ & 15.4 & 16.8 & 8.2 & 53.2 & 6.4 & 100.0 \\
\hline $66-75$ & 5.0 & 11.0 & 8.7 & 67.3 & 8.0 & 100.0 \\
\hline 76 or more & 2.2 & 13.5 & 6.2 & 72.8 & 5.3 & 100.0 \\
\hline
\end{tabular}

Source: G. Hernández Licona, 2001.

a IMSS: Instituto Mexicano de Seguridad Social; ISSSTE: Instituto de Seguridad y Servicios Sociales de los Trabajadores del Estado.

unmindful of the need to save for old age. This is one of the main reasons why participation has been made compulsory. Table 3 uses data on Mexico to illustrate this myopia. It shows that participation in social security systems is low in the younger working age groups and peaks in the group aged 26 to 35 . The figures indicate that, initially, the most common occupational category comprises wage earners with and without social security. Among the older age groups there is a decline in both kinds of wage earners, while the proportion of independent workers increases and even surpasses 50\% of the economically active population. This is because wage earners amass experience and financial capital in their early years in the labour market, which later allows them to embark on independent activities and become self-employed.

\section{Contextual factors: employment levels}

Coverage is also affected by short-term factors, although the link is difficult to document because of the scarcity of adequate statistics. Chile's experience between 1981 and 1992, as illustrated in figure 3, shows that when unemployment rises there is a decline in the share of the EAP contributing to pension schemes. Hernández Licona (2001) reports a similar situation in Mexico.

This link arises, of course, because unemployment cuts the connection with social security institutions. The region lacks adequate protection mechanisms to counteract this. One option currently under discussion consists of unemployment insurance that includes continuation of social security payments.

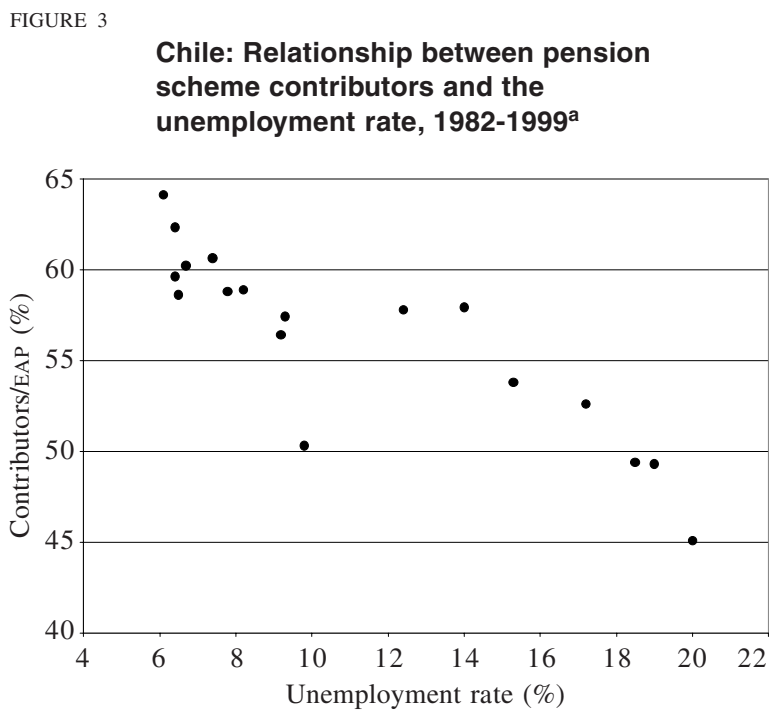

Source: Prepared by the authors on the basis of figures from the Instituto Nacional de Estadística (INE) and the Superintendencia de Adminstradoras de Fondos de Pensiones.

a Includes contributors to the Instituto de Normalización Previsional (INP) and to the Administradoras de Fondos de Pensiones. 


\section{III}

\section{Expanding the systems' coverage}

\section{The scale of the problem}

The analysis in the preceding section indicates that progress on coverage has been inadequate in the region, despite the changes that several countries have made to their pension systems. Given the influence of structural factors on this situation, the prospects for a spontaneous expansion of coverage are not bright in either the public or private schemes. Thus, the extension of coverage to those who currently do not or cannot participate in pension schemes will require specific public action based on acknowledgement of the particular factors that systematically exclude those individuals from the present systems. This article maintains that such a policy demands the right combination of contributory and noncontributory schemes. The non-contributory systems, moreover, should largely be geared to the poor sectors whose members are unable to save.

The groups that are normally excluded, and to which the expansion of coverage should accord priority, are independent urban workers in both the formal and informal sectors, as well as those in the countryside. Within these groups, women are particularly disadvantaged. It is very difficult for pension systems to include such groups, and the difficulties tended to mount in line with the informal sector's growing share of non-agricultural employment throughout the 1990s. The scale of the challenge is evident in table 4, which shows the significance of those segments of the labour market that are poorly covered as a percentage of the working population. In the region's more developed countries, about $30 \%$ of jobs are hard to cover with pension systems. In the poorer countries the share usually surpasses $45 \%$ of total employment, peaking at $69 \%$ in Bolivia.

\section{Some general criteria for policies to expand the coverage of contributory and non- contributory public pension schemes}

Since several proposals can be made on how to expand coverage, it is important to define some general criteria before discussing specific policy guidelines. The bulk of these criteria refer to public systems; given the scale and nature of the groups that have no coverage, it is these schemes that will be called upon to save the vulnerable from poverty. The system should be very carefully designed so as to circumvent the disincentive to participate in saving-based systems.

Most of the causes of limited coverage are longterm, and thus any policy of expansion must be sustainable if it is to have lasting effects. The system should therefore be designed to support fiscal burdens that correspond to the capacity to generate public resources and devote them to that purpose. Expansion programmes that are inadequately financed or based on fleeting windfalls in public finances are unsustainable and their effects will not last. In several countries the preparation of the public budget entails an estimate of the structural and cyclical components of spending and income. So too should the calculation of pension systems, with a view to creating an enduring prospect of greater coverage.

For the same reason, it is inadvisable to expand systems that are actuarially in deficit: an increase in the number of members will normally swell the deficit, making the benefits and the extended coverage unsustainable. Actuarial equilibrium should therefore be seen as a precondition for expanding coverage.

If universal coverage is the final goal, an effort should be made to ensure that those who could meet their consumption needs in old age on the basis of their own savings capacity are encouraged to do so, thus allowing scarce public funds to be devoted to those groups that lack such a capacity. To that end, people should be motivated to save for their old age, but the level of public guarantees (in the form of minimum guaranteed pensions for those participating in contributory public schemes) must be carefully set so as to avoid the moral hazard of inducing them to contribute only for a certain number of years and thereafter to evade payments by working in the informal sector. There must be a permanent incentive to contribute, perhaps by initially offering low guarantees and then rewarding every additional year (or two- or three-year period, for example) with marginal increases in the guarantee that, at least theoretically, would be slightly better than the marginal benefit of not working.

The level of basic benefits granted by noncontributory systems should be set at such a level that

EXPANDING THE COVERAGE OF PENSION SYSTEMS IN LATIN AMERICA • LUIS FELIPE JIMÉNEZ AND JÉSSICA CUADROS 
TABLE 4

Latin America: Share of employment that is difficult to cover with pension schemes, by country, 1998-1999"

(Percentage of total employment)

\begin{tabular}{lccc}
\hline Country & $\begin{array}{c}\text { Urban } \\
\text { employment } \\
\text { that is difficult } \\
\text { to cover }\end{array}$ & $\begin{array}{c}\text { Agricultural } \\
\text { employment } \\
\text { that is difficult } \\
\text { to cover }\end{array}$ & $\begin{array}{c}\text { Total } \\
\text { employment }\end{array}$ \\
$\begin{array}{lccc}\text { that is difficult } \\
\text { to cover }\end{array}$ \\
Argentina & 32.2 & n.d. & 32.2 \\
Uruguay & 34.9 & n.d. & 34.9 \\
Chile & 25.9 & 3.9 & 29.8 \\
Brazil & 33.3 & 13.2 & 46.4 \\
Mexico & 30.1 & 6.9 & 37.1 \\
Venezuela & 43.5 & 4.0 & 47.4 \\
Panama & 20.5 & 12.7 & 33.3 \\
Costa Rica & 17.3 & 4.7 & 22.0 \\
Colombia & 29.3 & 7.9 & 37.2 \\
Paraguay & 27.5 & 21.7 & 49.2 \\
El Salvador & 27.8 & 10.8 & 38.6 \\
Ecuador & 31.7 & n.d. & 31.7 \\
Dominican Rep. & 26.8 & 11.2 & 38.0 \\
Guatemala & 20.5 & 20.1 & 40.6 \\
Bolivia & 36.6 & 32.7 & 69.3 \\
Honduras & 24.5 & 20.7 & 45.2 \\
Nicaragua & 26.0 & 17.8 & 43.8 \\
\hline
\end{tabular}

Source: ECLAC (2001).

a Countries ranked by 1995 per capita GDP.

b Non-professional, non-technical workers in private establishments of up to five employees or self-employed staff, unwaged family workers and domestic employees.

c Self-employed workers and unwaged family workers in agriculture.

they do not constitute a disincentive to work once a certain age has been reached or some other condition of eligibility has been met. The upper limit should be set to strike a balance between two criteria, depending on the conditions in each country. If the basic aim is to forestall poverty in old age, the pension should not exceed the estimated poverty line in each country. If the aim is to preserve the incentive to work, the upper limit should be below the minimum wage, as long as the latter is properly calculated at a level close to the reserve wage for unskilled labour, if this is the section of the labour force that is to receive the pension. ${ }^{10}$

Another reason to forego generous benefits in noncontributory systems is that such benefits discourage membership of and payments to contributory schemes,

\footnotetext{
${ }^{10}$ In many countries of the region the minimum wage is decided on the basis of other criteria. Hence its use to determine minimum pensions might cause sharp distortions.
}

giving the State responsibility for the welfare of those who could have helped save for their old age. The expansion of these schemes must therefore be carefully calibrated by focusing the non-contributory benefits on those sectors that cannot save. This can be done, for example, by means testing (of income and assets), selfselection mechanisms or taxes that offset any unwanted distributive effects of universal pensions.

It should be kept in mind, moreover, that pension systems seek to provide income in old age so as to guarantee a certain level of consumption. It is not always the case, however, that such consumption needs are best met through the provision of monetary income. If programmes are to be sustainable and have lasting effects, some of the consumption needs of those people who are not covered by contributory schemes can be met more effectively through the direct provision of goods and services, such as health care and access to medicines. Non-contributory pension systems, therefore, should be viewed as one link in the network of social protection rather than as an alternative to contributory schemes.

Last but not least, the subsidy elements to be introduced should be as progressive as possible or distribution-neutral.

\section{Some policy recommendations}

\section{a) Redesigning pension systems}

One significant criticism is that social security systems in most countries of the region emulate those previously implemented in developed countries, which have higher levels of urbanization and less informal activity. One proposal for securing universal coverage in the region is the creation (or enlargement, as the case may be) of a non-contributory scheme that gives a basic pension to all those who meet certain conditions, such as age or residence in the country. ${ }^{11}$ Such a universal system would not replace the existing contributory schemes, but it would offer the benefits of timely coverage of the whole population and low operating costs. Possible adverse effects in terms of discouraging saving and work could be mitigated by setting the pension at an appropriate level, in line with the criteria outlined above.

The main difficulty with this kind of system is the cost. Table 5 presents estimates of the cost of a non-

\footnotetext{
${ }^{11}$ There are universal systems without means tests in New Zealand, Namibia, Botswana and Mauritius. Other schemes demand such tests (see Willmore, 2001).
} 
TABLE 5

Latin America: Estimates of the cost of a universal pension ${ }^{a}$

\begin{tabular}{|c|c|c|c|c|c|c|c|c|c|}
\hline \multirow[t]{2}{*}{ Country } & \multirow{2}{*}{$\begin{array}{l}\text { Population } \\
\text { over } 65 \\
\% \text { of total }\end{array}$} & \multirow{2}{*}{\multicolumn{2}{|c|}{$\begin{array}{cc}\begin{array}{c}\text { Urban } \\
\text { indigence } \\
\text { line }\end{array} & \begin{array}{c}\text { Urban } \\
\text { poverty } \\
\text { line }\end{array} \\
& \\
\text { Dollars/month }\end{array}$}} & \multirow{2}{*}{$\begin{array}{c}\text { Minimum } \\
\text { wage }\end{array}$} & \multirow{2}{*}{\begin{tabular}{|c|}
$\begin{array}{c}\text { Per capita } \\
\text { GDP }\end{array}$ \\
Dollars/year
\end{tabular}} & \multicolumn{3}{|c|}{$\begin{array}{l}\text { Cost, as } \% \text { of GDP, of a universal } \\
\text { pension equivalent to: }\end{array}$} & \multirow{2}{*}{$\begin{array}{c}\text { Central } \\
\text { government } \\
\text { current } \\
\text { income }^{b}\end{array}$} \\
\hline & & & & & & $\begin{array}{l}\text { Indigence } \\
\text { line }\end{array}$ & $\begin{array}{l}\text { Poverty } \\
\text { line }\end{array}$ & $\begin{array}{l}\text { Minimum } \\
\text { wage }\end{array}$ & \\
\hline \multicolumn{10}{|c|}{$\begin{array}{l}\text { Countries at an incipient } \\
\text { or early transition stage }\end{array}$} \\
\hline Nicaragua & 3.1 & 26.3 & 52.7 & & 471.2 & 2.1 & 4.2 & & 25.8 \\
\hline Honduras & 3.4 & 39.3 & 78.6 & 69.1 & 691.2 & 2.3 & 4.6 & 4.1 & 18.7 \\
\hline Bolivia & 4.0 & 28.0 & 56.1 & 55.7 & 959.7 & 1.4 & 2.8 & 2.8 & 19.8 \\
\hline Guatemala & 3.5 & 40.7 & 81.5 & 73.5 & 1547.6 & 1.1 & 2.2 & 2.0 & 11.0 \\
\hline Paraguay & 3.5 & 42.0 & 83.9 & 178.3 & 1602.7 & 1.1 & 2.2 & 4.7 & 20.5 \\
\hline El Salvador & 5.0 & 33.5 & 66.9 & 122.1 & 1736.8 & 1.2 & 2.3 & 4.2 & 11.3 \\
\hline \multicolumn{10}{|l|}{$\begin{array}{l}\text { Countries in } \\
\text { mid-transition }\end{array}$} \\
\hline Ecuador & 4.7 & 19.3 & 38.5 & 52.5 & 1404.4 & 0.8 & 1.5 & 2.1 & 19.6 \\
\hline Colombia & 4.7 & 37.3 & 74.6 & 139.1 & 2267.8 & 0.9 & 1.9 & 3.5 & 10.8 \\
\hline Dominican Republic & 4.5 & 42.1 & 84.3 & & 2479.0 & 0.9 & 1.8 & & 15.3 \\
\hline Venezuela & 4.4 & 78.8 & 155.9 & 174.7 & 3036.8 & 1.4 & 2.7 & 3.0 & 16.3 \\
\hline Panama & 5.5 & 40.7 & 81.4 & 25.5 & 3264.4 & 0.8 & 1.6 & 0.5 & 20.0 \\
\hline Costa Rica & 5.1 & 37.5 & 75.1 & 217.4 & 3625.2 & 0.6 & 1.3 & 3.7 & 12.5 \\
\hline Brazil & 5.2 & 26.7 & 66.2 & 74.5 & 4220.6 & 0.4 & 1.0 & 1.1 & 11.4 \\
\hline Mexico & 4.7 & 56.8 & 113.6 & 85.6 & 4583.4 & 0.7 & 1.4 & 1.1 & 13.5 \\
\hline \multicolumn{10}{|c|}{$\begin{array}{l}\text { Countries at an advanced } \\
\text { transition stage }\end{array}$} \\
\hline Chile & 7.2 & 40.9 & 81.8 & 163.1 & 5128.5 & 0.7 & 1.4 & 2.7 & 21.0 \\
\hline Uruguay & 12.9 & 56.4 & 112.9 & 88.6 & 5930.0 & 1.5 & 2.9 & 2.3 & 19.2 \\
\hline Argentina & 9.7 & 71.6 & 143.3 & 200 & 7434.9 & 1.1 & 2.2 & 3.1 & 10.8 \\
\hline
\end{tabular}

Source: Prepared by ECLAC on the basis of official figures.

a According to 1999 data.

${ }^{\mathrm{b}}$ Excludes social security contributions and transfers to local government.

contributory universal pension for all those over 65 , expressed as a share of GDP. It takes account of different options for the pension level and the progress that the countries have made in the demographic transition. The table offers estimates of three alternatives for a basic universal pension: i) one that guarantees those over 65 an income equivalent to the indigence line, which covers solely food costs, ii) another equivalent to the poverty line, and iii) a pension equal to the minimum wage. This last is the most burdensome option.

The table shows that for countries in the early stages of the demographic transition, the cost of a universal pension to forestall poverty in old age stands at about $3 \%$ of GDP, even though the eligible population is not yet particularly large. The high cost springs from the fact that per capita output in these countries is among the lowest in the region. For countries at a later stage of the transition the cost falls to an average of $1.7 \%$ of GDP because income levels more than offset the higher proportion of people over 65 , relative to the first group of countries. Lastly, for countries at an advanced stage of demographic transition the cost rises again to $2.2 \%$ because a higher proportion of the population is eligible.

The main source of funds for such a programme is the central government's current income, which averages $16 \%$ of GDP. ${ }^{12}$ Setting this figure against the

\footnotetext{
${ }^{12}$ Current public revenue figures are often hard to compare between countries. Those in table 5 do not include income derived from public utilities or transfers to local government. The latter are more significant in countries with federal systems. Since the degree of private participation in social security differs from country to country, social security contributions have been deducted from the data.
} 
estimated costs, it is clear that a programme of universal coverage offering a rather modest pension -equivalent to the level of the poverty line- would call for about $10 \%$ to $18 \%$ of government income. ${ }^{13}$ For most countries in the region, therefore, a universal programme such as this would exert significant pressure on public funds, a circumstance aggravated by the status of the demographic transition and by legitimate demands for benefits above the poverty line.

Because these two key conditions are present (the vulnerability of those who for various reasons cannot save for old age and the scarcity of public funds), Latin American pension schemes should be mixed. The dearth of resources makes it crucial to devise appropriate institutional arrangements that support the saving capacity of those who can save and thereby release the State from that responsibility, especially towards the more affluent groups. At the same time, the need to protect those whose participation faces structural obstacles, coupled with the lack of resources, underscores the importance of non-contributory schemes and the need to focus them on the poorest groups.

As to contributory schemes with low contribution density among low-income groups and women, systems marked by a close link between contributions and benefits will be unable to offer such groups a decent level of income; about $45 \%$ of their members will be eligible for a guaranteed minimum pension (Arenas de Mesa, 1999). In other words, in a pension system with defined contributions those groups will remain underprotected and the State will have to bear the substantial cost of providing guaranteed pensions.

These considerations have given rise to the proposal, now adopted by some countries in planning their systems, to include the solidary financing of a basic pension. The reforms in Argentina and Uruguay involve an individual capitalization component but they retain a basic pension financed through an unfunded system, which confers some degree of solidarity on the financing. ${ }^{14}$ As mentioned earlier, such systems should take the precautions needed to avert any strategic conduct by the participants that might affect the solvency of the unfunded component.

\footnotetext{
${ }^{13}$ Current income, less social security contributions, has been used as the source for two reasons. First, the capital account is not used to finance recurring current spending (pensions). Second, this programme is not intended to replace the contributory scheme, which will continue to be financed by social security contributions. ${ }^{14}$ The process of social welfare reform in Costa Rica has also included proposals to retain common financing of a basic pension.
}

The system described here is potentially superior to schemes based solely on individual accounts, since it allows risks to be spread more widely. Individual capitalization schemes concentrate the risks (potential financial losses, jobs and income) on the participants and allow only financial diversification. Unfunded systems, for their part, are exposed to demographic risk (an increase in dependency rates) and the possibility of financial diversification is limited because the accumulation of funds is normally low. They can, however, feature some degree of intergenerational diversification because the risks are shared. Thus a combination of the two might offer a better risk spread from both the financial and intergenerational standpoints. ${ }^{15}$

Lastly, pension systems are incomplete if they lack mechanisms (operationally separate, in all likelihood) to deal with interruptions of contributions as a result of unemployment and maternity. The region has recently witnessed a resurgence of interest in unemployment insurance schemes. Plans to provide income during periods of unemployment should also involve (at least for some period) the continuation of contributions to pension systems, the payments being made from the unemployment insurance. The continuation of contributions in this way would obviate the risk that temporary losses in present income might become permanent losses in future income (lower pensions), and there would be a decline in the fiscal burden needed to provide guaranteed minimum pensions.

\section{b) Lessening the disincentives to participate in contributory pension schemes}

A second line of action is to reduce the alternative cost of participating in contributory schemes for independent and self-employed workers, and to enhance the right of participants to choose between risk and gain.

From this perspective, the voluntary expansion of those systems' coverage is constrained by their inflexibility and the limited range of products on offer, circumstances that prevent contributors from influencing what happens to their savings. The anticoverage bias arising from irrevocability and the contributions' lack of liquidity would diminish if, under certain conditions and constraints, the accumulated funds could be accessed and used for purposes that their

\footnotetext{
${ }^{15}$ Recent experience shows that both private and public institutions are subject to the risk of political interference. No design can diversify that risk.
} 
owners valued highly. The accumulated resources, however, would probably decline.

In theory, access to the funds is restricted so as to prevent their diversion towards ends that could endanger the provision of adequate pensions, but the lack of access acts as a disincentive that could lead to fewer accumulated resources. That could be mitigated, and future pension levels could be safeguarded, by placing limits on withdrawals and providing options for the return of funds. To avoid moral hazards in the face of guaranteed minimum pensions in the contributory scheme, access to the funds should entail the loss of the guarantee, at least until they are returned to the scheme.

Second, contributors should be able to decide between risk and gain throughout their membership period. They should be allowed to choose between various fund management companies and different funds with varying asset compositions, so as to make membership of the scheme attractive to those who are more risk-averse. From the viewpoint of dependent workers for whom membership and contributions are obligatory, access to different products offers partial compensation for the compulsory nature of the system. In other words, since the contribution is mandatory, it is at least equitable and fair that contributors should not be exposed to more risk than they deem proper. Chile recently reformed its pension system in such a manner.

Independent workers are discouraged from joining schemes because of flaws in the tax system. Unlike dependent workers, independent workers in some countries (Chile, for example) cannot deduct their contributions to the pension system from their tax payments. This involves a degree of double taxation, since both savings and subsequent pension income are taxed (Arenas de Mesa, 2000).

\section{c) Rectifying short-sighted views of the need to save for old age}

Low participation rates spring from short-sighted consumption and saving decisions, inducing governments to oblige dependent and independent workers to join pension schemes. Unfortunately there is no evidence that this has expanded coverage. Thought should be given to ways of educating potential participants and making pension schemes a more attractive saving option. Even in developed countries, however, the results of information and education campaigns on the need to save for old age have been discouraging. ${ }^{16}$ d) Options for expanding coverage among women

As mentioned earlier, several factors conspire to constrain coverage among women. Given the structural features of the region's labour markets and public sectors, the debate on how to tackle this matter is in its infancy. Here we shall deal solely with the question of widening coverage, since the quality of the benefits offered to women and other equity issues are beyond the scope of this article.

In developed countries, issues of gender equity in social security gained prominence in the 1990s. Matters such as the difference in retirement age, the credit in assessed years for women who care for children and the elderly, coverage for women who work at home, part time or in domestic service, or whose work is seasonal (in agriculture, for example), were analysed and addressed in social security reforms in the 1990s.

Examination of the reasons for limited coverage discussed above reveals that contributory regimes and the changes made to them will be of little use in expanding coverage among women. Systems based on formal and stable job patterns are rendered ineffective by women's lesser participation and poor integration in the labour market. This is particularly true for women from lower-income groups. Perhaps the only viable alternative for the latter, therefore, consists of noncontributory schemes that avoid moral hazard and that focus on those who lack the capacity to save or other means of ensuring income in old age. Since women comprise a higher proportion of those outside the labour market and those working in the informal sector, such programmes would implicitly expand coverage of women and would do so to a greater extent.

Several proposals have been made on how to set up special systems for situations in which low-income women are in the majority, such as work that is highly seasonal or sporadic. A recent proposal in Chile recommended that temporary female workers should have the right to a minimum pension under conditions that were adapted to the circumstances of their work. ${ }^{17}$ Such special schemes are helpful inasmuch as they

\footnotetext{
${ }^{16}$ In its electronic edition of 15 April 2002, the Financial Times reported that a pilot programme conducted by the Government and pension funds of the United Kingdom, designed to inform thousands of participants of the meagre pensions that they would receive if they did not increase their contributions, prompted a positive response in under $10 \%$ of cases.

${ }^{17}$ Financial feasibility studies indicated that the proposal would give rise to a burdensome system, and hence a final proposal is still being assessed.
} 
focus on low-income women and continue encouraging them to save for old age. If they are confined to certain types of work, however, they lessen the portability of the benefits and weaken labour mobility, which are negative outcomes from the perspective of pension

\section{IV}

\section{Conclusions}

Although the data on pension system coverage are inconsistent and incompatible, it is clear that coverage is heavily dependent on structural economic factors and that substantial sectors of the population cannot join contributory schemes. The potential coverage of contributory systems is determined mainly by the level of per capita GDP and the importance of the labour market's informal and agricultural sectors. Recent experience does not suggest that private schemes in which contributions and benefits are more closely aligned are particularly helpful in expanding coverage, although they do help make the system more solvent. The provision of universal protection that forestalls poverty in old age demands a new design.

The foregoing prompts the conclusion that if the whole population is to be protected, the right combination of contributory and non-contributory schemes will be needed (i.e., systems that bring together elements of social insurance and social security). In view of the public cost of non-contributory schemes, which table 5 shows to be a significant share of GDP, they should be expanded gradually and focused on poor groups whose members are unable to save. Their benefits should be carefully set so as to avoid improper incentives that undermine contributory schemes and/ system design and from the standpoint of resource allocation. The proliferation of special schemes, moreover, could again give rise to the fragmentation, inequality and financial disequilibrium that previously characterized the region's pension systems. or saving for old age. Non-contributory systems seem to be the main option for expanding coverage of women, whose disadvantaged integration in the labour market lessens their prospects of benefiting from systems based on formal job patterns.

A substantial share of the members of contributory schemes are underprotected because of the irregularity of their work, and women in particular find it hard to establish continuous contribution records. ${ }^{18}$ According to projections, this will be a serious problem in the future. The main response to it is to include in pension systems an unfunded component that finances a basic pension in a spirit of solidarity, in conjunction with a system of savings.

In sum, the provision of universal coverage requires a combination of social insurance, social security institutions and solidarity in financing part of the benefits. A mixed system, involving private and public components (contributory and noncontributory), with pensions funded on the basis of saving and of solidary and tax-related financing, is better than others that disregard the nature of the region's labour markets.

${ }^{18}$ See, among others, Arenas de Mesa (1999) and Uthoff (2001).

\section{Bibliography}

Acosta, O.L. and U. Ayala (2001): Reformas pensionales y costos fiscales en Colombia, Financiamiento del desarrollo series, No. 116, LC/L.1630-P, Santiago, Chile, Economic Commission for Latin America and the Caribbean (ECLAC), November. United Nations publication, Sales No.: S.01.II.G.167.

(2002): Políticas para promover una ampliación de la cobertura de los sistemas de pensiones en Colombia, Financiamiento del desarrollo series, No. 118, LC/L.1724-P, Santiago, Chile, Economic Commission for Latin America and the Caribbean (ECLAC), April. United Nations publication, Sales No.: S.02.II.G.39.
Acuña, R. and A. Iglesias (1991): Chile: Experiencia con un régimen de capitalización, 1981-1991, Santiago, Chile, Economic Commission for Latin America and the Caribbean (ECLAC).

Arenas de Mesa, A. (1999): Efectos fiscales del sistema de pensiones en Chile: Proyecciones del déficit previsional 1999-2037, unpublished.

(2000): Cobertura previsional en Chile: Lecciones y desafíos del sistema de pensiones administrado por el sector privado, Financiamiento del desarrollo series, No. 105, LC.L.1457-P, Santiago, Chile, Economic Commission for Latin America and the Caribbean (ECLAC), December. United Nations publication, Sales No.: S.00.II.G.137. 
Arenas de Mesa, A. and H. Hernández (2001): Análisis, evolución y propuestas de ampliación de la cobertura del sistema civil de pensiones en Chile, in F.M. Bertranou (comp.), Cobertura previsional en Argentina, Brasil y Chile, Santiago, Chile, International Labour Office.

Barr, N. (2000): Reforming pensions: Myths, truths and policy choices, IMF Working Paper, No. 139, Washington, D.C., International Monetary Fund (IMF), August.

Diamond, P. (2001): Towards an optimal social security design, CeRP Working Paper, Center for Research on Pensions and Welfare Policies (CeRP), April.

ECLAC (Economic Commission for Latin America and the Caribbean) (2000): Social panorama of Latin America 19992000, LC/G.2068-P, Santiago, Chile. United Nations publication, Sales No.: E.00.II.G.18.

(2001): Social panorama of Latin America 2000-2001, LC/G.2138-P, Santiago, Chile. United Nations publication, Sales No.: E.01.II.G.141.

(2002): Latin America and the Caribbean: Population estimates and projections, 1950-2050, Demographic Bulletin, year 35, No. 69, LC/G.2152-P, Population Division of ECLACLatin American and Caribbean Demographic Centre (CELADE), January. United Nations publication, Sales No.: E.01.II.G.179.

Fox, L. and E. Palmer (2001): Pension reform in Europe in the 90's and lessons for Latin America, Financiamiento del desarrollo series, No. 114, LC/L.1628-P, Santiago, Chile, Economic Commission for Latin America and the Caribbean (ECLAC), November. United Nations publication, Sales No.: E.01.II.G.166.

Hernández Licona, G. (2001): Políticas para promover una ampliación de la cobertura de los sistemas de pensiones: el caso de México, Financiamiento del desarrollo series, No. 107, LC/L.1482-P, Santiago, Chile, Economic Commission for Latin America and the Caribbean (ECLAC), January. United Nations publication, Sales No.: S.01.II.G-15.

ILO (International Labour Organization) (2000): Panorama laboral de América Latina y el Caribe, 2000, Lima, ILo Regional Office for Latin America and the Caribbean.

Jiménez, L.F. and N. Ruedi (1998): Determinants of inequality among urban households, CEPAL Review, No. 66, LC/G.2049-P, Santiago, Chile, Economic Commission for Latin America and the Caribbean (ECLAC), December.

Lora, E. and C. Pagés (2000): Hacia un envejecimiento responsable: Las reformas de los sistemas pensionales en América Latina, Washington, D.C., Inter-American Development Bank (IDB), October.

Mastrángelo, J. (1999): Políticas para la reducción de costos en los sistemas de pensiones: el caso de Chile, Financiamiento del desarrollo series, No. 86, LC/L.1246-P, Santiago, Chile,
Economic Commission for Latin America and the Caribbean (ECLAC), September. United Nations publication, Sales No.: S.99.II.G.36.

Mesa-Lago, C. and A. Arenas de Mesa (1998): The Chilean pension system: Evaluation, lessons and challenges, in M.A. CruzSaco and C. Mesa-Lago (comps.), Do options exist?: The reform of pension and health systems in Latin America, Pittsburgh, Pennsylvania, University of Pittsburgh Press.

Mesa-Lago, C., M.A. Cruz-Saco and L. Zamalloa (1990): Determinantes de los costos y la cobertura del seguroseguridad social en la América Latina, El trimestre económico, vol. 57 , No. 1.

Packard, T. and N. Shinkai (undated): The reach of social security in Latin America: A look at the determinants of coverage in the region, Washington, D.C., World Bank/Inter-American Development Bank (IDB).

Palacios, R. and M. Pallarès-Miralles (2000): International patterns of pension provision, Washington, D.C., World Bank, April.

Rabelo, F. (2001): Pension systems for public employees in Brazil: Options for reform, unpublished.

Rodríguez, A. and F. Durán (2000): Costos e incentivos en la organización de un sistema de pensiones, Financiamiento del desarrollo series, No. 98, LC/L.1388-P, Santiago, Chile, Economic Commission for Latin America and the Caribbean (eClaC), June. United Nations publication, Sales No.: S.00.II.G.63.

Schmidt-Hebbel, K. (1998): Does pension reform really spur productivity and growth?, Working Paper, No. 33, Santiago, Chile, Central Bank of Chile.

Schulthess, W. and G. Demarco (1993): Sistema de pensiones en América Latina. Argentina: Evolución del sistema nacional de previsión social y propuesta de reforma, Colección estudios políticos y sociales, Santiago, Chile, S.R.V. Impresos.

Superintendencia de Administradoras de Fondos de Pensiones (2002): Boletín estadístico, Santiago, Chile, January-April.

Uthoff, A. (2001): La reforma del sistema de pensiones en Chile y desafíos pendientes, Financiamiento del desarrollo series, No. 112, LC/L.1575-P, Santiago, Chile, Economic Commission for Latin America and the Caribbean (ECLAC), June. United Nations publication, Sales No.: S.01.II.G.118.

Uthoff, A. and R. Szalachman (1991, 1992, 1994): Sistema de pensiones en América Latina y el Caribe, 3 volúmenes, Santiago, Chile, Economic Commission for Latin America and the Caribbean (ECLAC).

Willmore, L. (2001): Universal pensions in low-income countries, New York, Division for Public Administration and Development Management (DPADM), Department of Economic and Social Affairs (DESA), United Nations. 